\title{
Democracy large and small Reforming the EU to sustain democratic legitimacy on all levels
}

Europe is trapped, Fritz Scharpf says, between national democracies undermined by nonpolitical forces and a European democracy paralysed by consensus and veto. Legitimate reform, he argues, must allow democracy to flourish on both levels at the same time, even if 'European integration' loses some of its unitary appeal in the process.

Left-of-centre political parties, unions and public intellectuals in the European Union are intensely aware of ever-increasing external constraints on national policy choices in areas such as capital taxation, public services, welfare benefits, pensions, employment and labour relations. They tend to ascribe these constraints to the intensity of capitalist competition in the global economy, and to the direct and indirect impacts of global financial markets on public policies, domestic economies and corporate governance. And they tend to place their hopes for change on the further transfer of sovereignty rights to a democratic EU that is large and powerful enough to withstand global economic and financial pressures and to have a significant voice in shaping international responses to global challenges.

Compared with the trentes glorieuses that followed the second world war, there is no question that today the capacity of democratic politics to shape national economies and societies has been greatly reduced, and that since the fall of the Berlin wall economic globalisation has dramatically increased. But it is also true that European integration has severely reduced the capacity of EU member states to cope with the economic challenges they face, while the union's own problem-solving capacity is limited by political disagreement. Worse yet, the disastrous economic and democratic impacts of the monetary union were entirely brought about by misguided ambitions for further integration. Nevertheless, proEuropean social democrats continue to demand more integration, to be combined with institutional reforms to transform the union into a parliamentary democracy. Then, it is hoped, Europe-wide voter majorities might finally be mobilised to bring about social-democratic policies on the European level. However, even putting aside considerations of political feasibility, this vision seems incompatible with the essential requirements of democratic legitimacy. 


\section{THE LEGAL AND POLITICAL CONSTRAINTS ON EUROPEAN DEMOCRACY}

In 1957, via the Treaty of Rome, the 'original six' agreed to create a common market by abolishing tariff barriers and harmonising national rules that acted as non-tariff barriers to trade. However, these national governments had failed to anticipate the coup-d'état of the European Court of Justice, which in 1963 and 1964 postulated the supremacy and direct effect of European law. In substantive terms this meant that all European law and its judicial interpretation would gain constitutional priority over the laws and constitutions of member states. As a consequence, 'integration through law' and judicial action could take over if legislative integration was impeded by political disagreement.

The doctrine gained practical importance after the economic crises of the 1970s revived academic and political support for neoliberal beliefs in the efficiency of unfettered competition in deregulated markets. Economists in the European Commission tended to share these beliefs, but that was not true of all governments. In this context, integration through law became a prime mover in the liberal transformation of European social-market economies. Interpreting treaty commitments to the free movement of goods, services, firms, workers and capital as individual rights, the court invited private litigants to challenge all national regulations and institutions that could be seen as impeding the exercise of their 'economic liberties' or their right to unfettered competition. Of course, not all such challenges succeeded, but those that did had the ratcheting effect of a constitutional rule that constrained the regulatory powers of EU member states. In effect, the deregulatory and liberalising impact of 'negative integration' removed a state's control over its own economic boundaries and exposed it to intra-European regulatory and tax competition. Beyond that, it has greatly reduced the capacity of democratic politics to deal with the challenges of economic globalisation at the national level.

Pro-European social democrats thus had to put their hopes on the possibility of 'positive integration' - that is, of common European rules replacing the national regulations the court had disallowed. But, unlike negative integration, positive integration cannot be achieved through the European court's case law. Instead, it requires 'political' legislation. This, however, is also bound by the court's interpretation of the treaties, which means that a lot of EU legislation has the effect of 'codification', systematising the case law.

Legislation under the prevailing rules of the 'community method' depends on an initiative by the European Commission, an absolute majority in the European parliament, and a qualified majority of government votes in the council. In short, it is an extreme case of a multiple-veto system in which political legislation presupposes very broad political agreement, something that is ever more difficult to obtain in the increasingly heterogeneous union. On issues which, among the old member states, would provoke conflict between market-liberal and social-democratic groups, consensus is practically out of the question; similarly, conflicts between old and new
"It was and is unreasonable for left-of-centre pro-European political parties and unions to expect either that political action at the European level can create a meaningful 'European social model', or that it can protect the existing socialmarket economies of EU member states against the pressures of cross-border competition or the impact of global capitalism." 
member states, or between creditor and debtor states in the eurozone, are also beyond resolution by European legislation. It therefore was and is unreasonable for left-of-centre pro-European political parties and unions to expect either that political action at the European level can create a meaningful 'European social model', or that it can protect the existing social-market economies of EU member states against the pressures of cross-border competition or the impact of global capitalism.

\section{MONETARY UNION: AN ECONOMIC AND DEMOCRATIC DEBACLE}

In their enthusiasm for European integration, most left-of-centre political actors and authors supported the act of monetary union, and even now only a few of them are willing to regard it as, in the words of Wolfgang Streeck, a 'frivolous experiment' whose defence may well tear apart the union. Its premise was that a common currency would homogenise the structural and institutional differences which for decades had determined the divergent trajectories of hard-currency and soft-currency political economies in Europe. However, some political economists predicted at the time that these structural characteristics would persist, and that uniform monetary policies would instead increase economic divergence and undermine the viability of the less competitive economies. And so it has come to pass.

Initially, the elimination of exchange-rate risks and a drastic fall of interest rates boosted credit-financed domestic demand, employment and wages in former soft-currency countries. In former hard-currency countries like Germany, by contrast, domestic demand was constrained by high real interest rates, rising unemployment and falling real wages. As a result, unit labour costs, real effective exchange rates and current accounts diverged dramatically. But when the bubble burst in 2008, interbank lending came to a sudden halt and credit-dependent eurozone economies were thrown into deep economic and financial crises - which ultimately provoked speculative attacks on state solvency in deficit economies and in turn the euro crisis of 2010.

That could and should have been the end of the monetary union. But, fearing the impact on their own banks and export industries, Germany and other surplus states decided to provide rescue loans to avert state insolvency in Greece, Portugal and Ireland. These loans were associated with strictly enforced 'conditionalities' that demanded severe fiscal cutbacks and incisive supply-side reforms - ostensibly to reduce the need for further credit. But it must have been clear that the depression of domestic demand was bound to deepen these countries' economic crises and thus to increase indebtedness even further. In this light, then, a more plausible explanation for the imposed measures lies in concerns about the huge current account deficits that the former softcurrency economies had accumulated under the perverse incentives of the monetary union, and which were seen as the ultimate cause of the speculative attacks on over-indebted states.

"In their
enthusiasm
for European
integration, most
left-of-centre
political actors
and authors
supported the
act of monetary
union, and even
now only a few of
them are willing
to regard it as,
in the words of
Wolfgang Streeck,
a frivolous
experiment."

"In their enthusiasm for European left-of-centre political actors and authors supported the act of monetary union, and even now only a few of them are willing to regard it as, in the words of Wolfgang Streeck, experiment." 
In a monetary union, of course, external imbalances of rising imports and stagnating exports - caused by above-average increases in prices and wages - could not be corrected by adjusting nominal exchange rates. So, in order to restore the 'confidence of the markets' they had to be reduced through what is called 'internal devaluation'. This is exactly what the conditionalities set out to achieve: fiscal austerity to reduce domestic demand, prices and imports, and supply-side reforms to reduce wages. And in terms of these objectives, the draconian measures are in fact succeeding: imports and nominal unit labour costs have been reduced and capital account balances have improved, allowing Ireland and Portugal to return to capital markets without paying significant risk premiums. Despite this 'success', austerity rules cannot be relaxed, as any rise in domestic demand would again produce imbalances, which in turn would raise the danger of speculative attacks.

For Greece and the other victims of the euro crisis, however, the economic and social costs of enforced internal devaluation have been catastrophic, with GDP declining by more than 20 per cent, unemployment reaching 25 per cent and youth unemployment 55 per cent in some years, and levels of poverty increasing. Although there is now some economic growth, there is no chance that former soft-currency economies (with the possible exception of Ireland) will return to pre-crisis levels of employment through export-led recovery. At the same time, export-based employment in Germany and similar hard-currency countries continues to benefit excessively from the continuing undervaluation of real effective exchange rates - something which the euro regime has not even attempted to correct. As a consequence, the political economy of the eurozone is now characterised by glaring north-south inequalities that can be directly attributed to the euro regime and which - if they should ever have to be put on the European political agenda - could cause political conflicts that would be disastrous for the union.

In the meantime, through the six-pack and two-pack regulations and the fiscal pact, a permanent euro regime has been installed that seems designed to avoid the possibility of open political confrontation. Its economic policy represents a generalisation of the conditionalities placed on debtor countries. Now all member states of the monetary union must avoid current account deficits and maintain fiscal austerity at all times. For any economy moving into a recession, therefore, fiscal reflation is ruled out, and the only permitted response will be internal devaluation through fiscal cutbacks and supply-side reforms aimed at achieving an export-led recovery. But if this strategy should succeed in reducing imports and generating exports, as did for Germany after 2005, then it will generate external surpluses, which then must be matched by external deficits elsewhere. For the eurozone as a whole, therefore, the euro regime amounts to a game of beggar-myneighbour. From a distributional perspective, moreover, it has created the institutional conditions for a vicious cycle of competitive internal devaluations that must exert continuous downward pressures on wages and public expenditures in all member states.

\section{"The political economy of the eurozone is now characterised by glaring north- south inequalities that can be directly attributed to the euro regime and which - if they should ever have to be put on the European political agenda - could cause political conflicts that would be disastrous for the union."}


Quite obviously, the euro regime could not rely on democratic governments to adopt of their own volition the unpopular policies that might be required to stabilise the single currency. In the wake of the euro crisis, conditionalities attached to rescue loans could be imposed by the bargaining power of creditor states in the Eurogroup council. The regime of the six-pack regulations, however, is meant to avoid the need for rescue loans in the first place, and thus cannot depend on an asymmetrical bargaining position. Instead, the European Commission is authorised to define binding recommendations for the fiscal, economic and social policies of member states found to be in excessive deficit or excessive macroeconomic imbalance, and to impose severe sanctions in case of non-compliance. Indeed, if the euro is to be stabilised, it could not be otherwise.

As the commission must be able to respond to the divergent and volatile conditions of national economies, its decisions cannot be predefined by parliamentary legislation. They must be discretionary and they must be able to discriminate among member states, and this exercising of discretion should not be subject to the hazards of intergovernmental bargaining. And so the commission's recommendations will become effective without a positive vote of the council - except that they can be suspended if a 'reverse qualified majority' can be persuaded to intervene. In other words, the six-pack and two-pack regulations have established a technocratic regime that is almost as authoritarian and almost as immunised against political intervention as is the European Central Bank's power of monetary blackmail that was used to force the governments of Cyprus and Greece into submission.

In short, the regime that is needed in order to defend the economically counterproductive monetary union is generating social inequality internally and transnational inequality externally, and is obliged to exclude political intervention and democratic accountability. From the perspective of proEuropean social democrats, therefore, the common currency ought to be dismantled or, if its beneficiaries prevent this, it should be allowed to collapse. This is, however, by no means a shared conclusion.

\section{DEMOCRATISING EUROPE}

Even if left-of-centre political parties and authors are concerned about the erosion of social-market economies and the rise of transnational and social inequality under the euro, they still tend to consider the further 'transfer of sovereignty' as a necessary part of the solution. And if they also acknowledge the technocratic-authoritarian character of the euro regime and the political self-paralysis of European legislation, the standard response is to reassert a commitment to the genuine democratisation of the EU. What is necessary, in their view, is to transform the union into a parliamentary democracy where the multiple-veto community method is replaced by majority rule, and where the technocratic authority of the European Commission is transformed into a government that is democratically accountable for its discretionary decisions.

At this point, I will not reiterate the obvious concerns about the political unfeasibility of such changes or about the inability of today's political

\section{"From the perspective of pro-European social democrats, therefore, the common currency ought to be dismantled or, if its beneficiaries prevent this, it should be allowed to collapse."}


parties and pathways of political engagement to link European governing powers to the interests and expressed preferences of European voters. Instead, I will argue against the legitimacy of majoritarian government in the present European Union on grounds of normative democratic theory.

In discussions of the alleged 'European democratic deficit', the focus is often on the lack of a Europe-wide and sufficiently 'thick' collective of European citizens capable of supporting the idea of collective selfgovernment - the 'no-demos' problem. But this perspective is so broad that it could only possibly affirm or deny the legitimacy of all exercises of European governing powers. Instead, I prefer to focus more narrowly on the legitimacy of majority decisions that would overrule the highly salient interests or normative preferences of a minority. This should be distinguished from the constitutional protection of basic human and civil rights and from specific minority rights granted by some constitutions. Here, the appropriate parallels are the constitutions of democratic federal states or of 'consensus democracies' in societies that are internally divided by ethnic, linguistic, religious or political cleavages. These polities generally depart from the majoritarian 'Westminster model' by having established institutional checks and balances and super-majoritarian decision rules which are designed to prevent 'persistent minorities' from being consistently ignored in the political process. A democratic European Union could do no less. Its internal divisions far exceed the ethnic, linguistic, religious and cultural heterogeneity of any national consensus democracy. And its member states are much more diverse in size, wealth, social institutions, policy legacies, historical memories and political aspirations than is true of the component polities of democratic federal states.

In fact, the multiple-veto community method of European legislation seems designed precisely to ensure that this legitimate diversity of societies and political economies will be respected in European political processes. It could not be replaced by the constitution of a Europe-wide Westminsterstyle democracy without destroying the legitimacy of the union. But, as noted already, Europe is paying a high price for respecting these limits. Institutionalised veto positions are, of course, not only used in defence of highly salient national practices and values, but may also be employed to advance any kind of interest - not least the interests of less-involved governments in maximising the price at which they could sell their vote. If consensus appears unattainable, the European Commission will not even try to launch a legislative initiative. And if it does, the eventual outcome of extended bargaining over relative advantages may be agreement on the lowest common denominator. In other words, on issues involving salient conflicts of interest, European legislation has never been, and is not now, an instrument of effective political action.

\section{THE SHAPE OF A DEMOCRACY-ENABLING CONSTITUTION}

The present state of the EU surely cannot please pro-European social democrats. Policy choices in national democracies are constrained by the liberalising and deregulatory imperatives of European law, and political action on the European level is constrained by divergent preferences and

\section{"On issues involving salient conflicts of interest, European legislation has never been, and is not now, an instrument of effective political action."}


the high level of consensus demanded by multiple-veto institutions. This is why the nonpolitical 'bypass' of integration through law has been effective in promoting economic liberalism even in periods when a majority of member states are governed by left-of-centre parties, and it is also why the euro crisis is being resolved in favour of capital interests through processes that are shielded against democratic intervention.

Moreover, proposals for institutional reforms that could improve the capacity for political action might conflict with basic norms of democratic legitimacy. In any case, such reforms would have to be processed under the even more constraining rules that govern treaty revision, whereby their adoption would depend on the agreement of all those who hold the power of veto. As a result, feasible changes would be incremental and path-dependent, and thus most likely to produce 'more of the same': more liberalisation, more internal devaluation, more centralised controls, and more technocratic-authoritarian rule.

We also know, however, that constraints on political feasibility are not written in stone. Deep crises may unsettle and delegitimise existing veto positions and open up windows of opportunity for previously unthinkable policy changes. We also know that the euro crisis is not yet over, and that the present euro regime may in fact increase the risk that it flares up once again. Should it do so, Angela Merkel's prediction of May 2010 may yet be confirmed: 'Scheitert der Euro, dann scheitert Europa.' But if the euro should indeed fail and so plunge Europe into an existential crisis, we must hope that the response will not again focus on saving the euro. It should be about saving Europe. And we should not only hope. We should also be ready with policy concepts and proposals which, to the best of our professional knowledge, would be pragmatically effective in avoiding or reducing the known deficiencies of today's EU, without violating basic norms of political legitimacy.

Thus, monetary and political economists might outline a Bretton-Woodsstyle European monetary regime designed to correct the failures of both the European Monetary Union and its predecessor. Of even greater importance, however, would be pragmatically useful ideas about a European political regime that allows for effective and democratically legitimate political action at the national and European levels at the same time. Ideally, this would motivate European lawyers to search for ways to loosen the excessive legal constraints imposed on national policy choices by European judicial intervention. At the same time, political scientists might explore opportunities for majoritarian political action on the European level that respect the constraints on democratic legitimacy discussed above - perhaps by loosening the rules on enhanced cooperation and by tolerating national opt-outs in order to facilitate political action by 'coalitions of the willing'. 'European integration' might lose some of its unitary appeal as a result. But European democracies might also be able to deal more effectively with the shared challenges that cannot be met by national democracies acting on their own.

Professor Fritz Scharpf is emeritus director of the Max Planck Institute for the Study of Societies.

\section{"If the euro should indeed fail and so plunge Europe into an existential crisis, we must hope that the response will not again focus on saving the euro. It should be about saving Europe."}

